\title{
Anticancer Activity of $S$-Allylmercapto-L-cysteine on Implanted Tumor of Human Gastric Cancer Cell
}

\author{
Yongkyu LeE, ${ }^{*, a}$ Hejin KIm, ${ }^{a}$ Jinhwa LeE, ${ }^{b}$ and Kyongtai $\mathrm{KIM}^{c, d}$ \\ ${ }^{a}$ Department of Food and Biotechnology, Dongseo University; ${ }^{b}$ Department of Clinical Laboratory Science, Dongseo \\ University; Jurae-Dong, Sasang-gu, San 69-1, Busan 617-716, Korea: and ${ }^{c}$ Department of Life Science, Division of \\ Molecular and Life Science, Pohang University of Science and Technology; and d Division of Integrative Bioscience \& \\ Biotechnology, Pohang University of Science and Technology; 790-784 San 31, Hyoja-dong, Nam-gu, Pohang, Gyungbuk \\ 790-784, Republic of Korea. $\quad$ Received November 16, 2010; accepted February 9, 2011
}

\begin{abstract}
Allylmercapto glutathione $S$-conjugate, $S$-allylmercapto-L-cysteine (SAMC), which is biotransformed from allyl sulfides and from naturally occurring water-soluble garlic derivatives, has been known to inhibit tumorigenesis. We found that SAMC was able to induce apoptosis in gastric cancer cells in vitro. We report that SAMC inhibited tumor growth rate by $31.36 \%$ and $37.78 \%$ at doses of 100 and $300 \mathrm{mg} / \mathrm{kg}$, respectively. Apoptosis in the implanted tumor cells was manifested by apoptotic characteristics, including morphological changes of chromatin crescent, cell shrinkage and membrane blebbing. The apoptosis index of $100 \mathrm{mg} / \mathrm{kg}$ and $300 \mathrm{mg} / \mathrm{kg}$ of SAMC was $20.74 \pm 2.50 \%$ and $30.61 \pm 2.42 \%$, respectively, by terminal deoxy-nucleotidyl transferase-mediated deoxyuridine triphosphate (dUTP) nick-end labeling (TUNEL) staining. The positive rate of B-cell lymphoma 2 (bcl-2) protein expression of control, $100 \mathrm{mg} / \mathrm{kg}$ SAMC and $300 \mathrm{mg} / \mathrm{kg}$ SAMC was $15.20 \pm 1.67 \%, 10.94 \pm 1.57 \%$, and $8.24 \pm 1.07 \%$, respectively, by immunohistochemical staining. The positive rate of bax protein expression of control, $100 \mathrm{mg} / \mathrm{kg}$ SAMC and $300 \mathrm{mg} / \mathrm{kg}$ SAMC was $15.30 \pm 1.90 \%, 23.18 \pm 1.81 \%$, and $25.26 \pm 3.03 \%$, respectively. We also observed decreases in bcl-2 mRNA and increases in bax mRNA by SAMC in a dose-dependent manner by reverse transcription-polymerase chain reaction (RT-PCR). These results suggest that SAMC may regulate bcl-2 and bax to induce apoptosis in transplanted tumor cells.
\end{abstract}

Key words apoptosis; $S$-allylmercapto-L-cysteine; tumor cell; bax protein; B-cell lymphoma 2 protein

Apoptosis is a complex process that involves many regulatory proteins such as B-cell lymphoma 2 (bcl-2) family proteins and other anti- or pro-apoptotic proteins. Of the major genes that regulate apoptosis, the anti-apoptotic bcl-2 gene and the pro-apoptotic bax gene are of particular interest. They have homologous amino acid sequences. ${ }^{1-4)} \mathrm{Bcl}-2$ resides on the cytoplasmic face of the mitochondrial outer membrane, endoplasmic reticulum, and nuclear envelope, and may damage these compartments and affect their behavior, perhaps by modifying the flux of small molecules or proteins. ${ }^{5)} \mathrm{Bcl}-2$ protects against various cytotoxic insults, such as UV-irradiation, cytokine withdrawal, and cytotoxic drugs. ${ }^{6}$ However, pro-apoptotic bax protein translocates to mitochondria upon exposure to apoptotic stimuli, ${ }^{7)}$ and induces cytochrome $c$ release and caspase activation in vitro ${ }^{8)}$ However, this process is blocked by anti-apoptotic proteins such as bcl2 and bcl-xL. ${ }^{9,10)}$ Therefore, anti-apoptotic bcl-2 subfamily proteins and pro-apoptotic bax subfamily proteins can oppositely regulate apoptosis through the control of cytochrome $c$ release, resulting in caspase activation. ${ }^{8}$ Overexpression of bax could promote cell death. ${ }^{11-15)}$ Conversely, overexpression of anti-apoptotic proteins such as bcl-2 could repress the function of bax. ${ }^{16-20)}$ Thus, it has been suggested that the ratio of the level of pro-apoptotic bax to that of anti-apoptotic bcl-2 determines whether a cell responds to an apoptotic signal. ${ }^{21)}$ In many cancer therapeutic studies, induction of apoptosis in tumor cells has been shown to be the generalized rule for anti-cancer mechanism conjoints. ${ }^{22-24)}$

Garlic, a plant within the Allium genus, has been used in many different cultures for disease prevention and treatment, especially for diseases of the gastrointestinal tract. Carcinogenesis studies have shown that allyl sulfides such as diallyl sulfide (DAS), diallyl disulfide (DADS), and diallyl trisulfide
(DATS), typical components of garlic, inhibit tumor cell proliferation in culture and chemically induced tumors in experimental animals, such as colon cancer, ${ }^{25)}$ breast cancer, ${ }^{26)}$ and lung cancer. ${ }^{27)}$ Most of these allyl sulfides, which are absorbed in the gastrointestinal tract, are also reported to biotransform to the corresponding allylmercapto glutathione $S$-conjugate after reacting with endogenous antioxidants, such as cysteine and reduced glutathione (GSH) ${ }^{28,29)}$ This allylmercapto glutathione $S$-conjugate, $S$-allylmercapto-L-cysteine (SAMC), which is biotransformed from allyl sulfides and from the naturally occurring water-soluble garlic derivatives, also inhibits tumorigenesis. ${ }^{30)}$ The fact that the chemical instability of these allyl sulfides does not limit their efficacy suggests that SAMC is the main bioactive metabolite. ${ }^{31)}$ Although not present in raw garlic, SAMC can be found as a stable orally bioavailable organosulfur compound in aged garlic. In addition, SAMC reportedly inhibits growth and induces apoptosis in SW480 and HT 29 human colon cancer cells $^{32)}$ and prostate cancer cells. ${ }^{33)}$ Our group also reported that SAMC induces apoptosis in primary gastric cancer cells. ${ }^{34)}$ SAMC exhibits apoptotic effects through down-regulation of bcl-2/bax proteins and activation of caspase- 3 in the gastric cancer cell line.

Despite the abundant in vitro evidence of the effects of garlic-related compounds, the in vivo anticancer effect of SAMC has rarely been reported. This study was designed to investigate the apoptotic effect of SAMC on implanted tumors of human gastric cancer cells in nude mice. Understanding the relationship between apoptosis by SAMC and expression of bcl-2/bax in vivo may allow for its clinical application. 


\section{MATERIALS AND METHODS}

Chemicals $S$-Allylmercapto-L-cysteine (SAMC) was a generous gift from Wakunaga Pharmaceutical Co., Ltd. (Hiroshima, Japan). It was fed to mice as an acidified ( $\mathrm{pH}$ 4.5) suspension of $30 \mathrm{mg} / \mathrm{ml}$ in $10 \%(\mathrm{w} / \mathrm{v})$ dextrose, $1 \%$ (w/v) gum Arabic (Sigma-Aldrich, St. Louis, U.S.A.). Adriamycin was used as a positive control. In situ cell detection kit, anti-bcl-2 and anti-bax monoclonal antibodies were purchased from IMGENEX Co. (San Diego, CA, U.S.A.). Male BALB/c nude mice (6 week old, 19-23 g) were obtained from Central Lab. Animal Inc. in Korea.

Cell Culture The previously described technique was used. $^{34)}$ Human stomach cancer cells, MKN-45, from KCLB (Korean Cell Line Bank) were cultured in RPMI 1640 media with $10 \%$ fetal bovine serum (FBS).

Tumor Implantation $5 \times 10^{6}$ cells $/ 0.2 \mathrm{ml} / \mathrm{mice}$ of human gastric cancer cells (KMN-45) were injected into subcutaneous tissues of nude mice. The animals commenced treatment on day 2 of control (vehicle, $n=7$ ), $100 \mathrm{mg} / \mathrm{kg}$ (low dose) $S$-allylmercapto-L-cysteine $(n=7)$, and $300 \mathrm{mg} / \mathrm{kg}$ (high dose) $S$-allylmercapto-L-cystein $(n=7)$ by daily orogastric feeding and adriamycin $(2 \mathrm{mg} / \mathrm{kg})$, a positive control, were daily injected intraperitoneally. Then, changes of tumor volume were measured with Calipus (Mitutoyo Corp., Japan) twice a week, and tumor inhibition rate of each group was calculated according to the following formula.

$$
\text { inhibitory rate (IR) of tumor growth }=\frac{C\left(V_{1}-V_{0}\right)-T\left(V_{1}-V_{0}\right)}{C\left(V_{1}-V_{0}\right)}
$$

Where $C$ is control group, $T$ is treated group, $V_{1}$ is the volume before treatment $\left(\mathrm{mm}^{3}\right), V_{0}$ is the volume after treated $\left(\mathrm{mm}^{3}\right)$.

This experiment was approved by the ethics committee for animal experiments at Dongseo University. When experimental animals are used, we follow the NIH guidelines for laboratory animals ${ }^{35)}$ and the Korean revised law for animal protection, 8852. All precautions were taken to care for the animals and to minimize any pain or discomfort.

Tumor Morphology After $24 \mathrm{~d}$ of treatment, the mice were euthanized by cervical dislocation and meticulously examined at postmortem. Paraffin-embedded tumor samples were cut into $1 \mu \mathrm{m}$ sections and attached on glass slides. After deparaffination and dehydration, samples are hematoxylin and eosin $(\mathrm{H} \& \mathrm{E})$ stained. H\&E stained ultrathin sections were observed with a light microscope (BX41TF, Olympus, Japan) with magnification $\times 1000$.

Tunel Assay Paraffin-embedded tumor samples were cut into $5 \mu \mathrm{m}$ sections and attached on silane coated glass slides (MUTO, Japan). Apoptosis in the tumor was measured with In Situ Cell Death Detection kit, POD (Roche, Germany). The tunel assay was carried out following the procedures directions. Tissue sections were deparaffinize in xylene, and hydrated through graded ethanol and then treated with proteinase K (20 $\mu \mathrm{g} / \mathrm{ml}$, Sigma, U.S.A.) for $20 \mathrm{~min}$ at RT. And endogenous peroxidase was blocked by $0.3 \% \quad \mathrm{H}_{2} \mathrm{O}_{2}$ in methanol for $15 \mathrm{~min}$ at RT. After the reaction, tissue sections were treated with Tris- $\mathrm{HCl}$ with $3 \%$ bovine serum albumin for $30 \mathrm{~min}$ and then incubated with tunel reaction mixture [containing terminal deoxynucleotidyl transferase from calf thymus (enzyme solution) and nucleotide mixture (label so- lution)] for $1 \mathrm{~h}$ at $37^{\circ} \mathrm{C}$ in a humidified chamber. Tissue samples were then combined with Converter-POD (containing anti-fluorescein antibody Fab fragments from sheep, conjugated with horse-radish peroxidase), followed by washing and DAB (Sigma, U.S.A.) color reaction. During the tunel procedure samples were washed in phosphate buffered saline (PBS). Tissue sections were counterstained by hematoxylin, dehydrated through graded ethanol, cleared in xylene, and mounted. Slides were observed with a light microscope (BX41TF, Olympus, Japan) for histological analysis. As a negative control, a section was incubated with label solution only instead of using the tunel reaction mixture. One thousand tumor cells were countered in five different sites of each tissue section at a magnification of $200 \times$. The apoptotic index (AI) was calculated as follows:

\section{$\mathrm{AI}(\%)=($ number of apoptotic cells $/$ total number of cells $) \times 100$}

Immunohistochemical Staining After deparaffination, the tissue sections were heated at $100^{\circ} \mathrm{C}$ for $20 \mathrm{~min}$ in $10 \mathrm{~mm}$ sodium citrate buffer with $0.05 \%$ Tween 20 (pH 6.0) for antigen retrieval. Then the sections were incubated with anti-Bax or anti-Bcl-2 antibodies (IMGENEX) at a 1:200 dilution at $4{ }^{\circ} \mathrm{C}$ overnight. After washed with PBS, the secondary antibody, Alexa Fluor ${ }^{\circledR} 488$ conjugated anti-rabbit immunoglobulin $\mathrm{G}$ ( $\mathrm{IgG}$ ) (Invitrogen), was added and cells were incubated at room temperature for $1 \mathrm{~h}$. Then cells were counterstained with $2 \mu \mathrm{g} / \mathrm{ml}$ Hoechst dye for visualizing the nuclei. Finally, cells were observed with fluorescence microscopy and anti-Bax or anti-Bcl-2 positive cells were detected. The number of whole cells and positive cells were counted using image analysis software (Image $\left.{ }^{\mathrm{TM}}\right)(\mathrm{NIH}$, Bethesda, MD, U.S.A.).

RT-PCR Tumor samples were cryopreserved in liquid nitrogen and total RNA was extracted as previously described technique. ${ }^{34)}$ Concentration of RNA was determined by the absorption at $260 \mathrm{~nm}$. The primers for bcl-2, bax and $\beta$-actin were as follows: $\beta$-actin (500 bp) $5^{\prime}$-GTGGGGCGCCCCAGGCACCA-3' (sense); 5'-CTCCTTAATGTCACGCACGATTTC-3' (antisense); bcl-2 (716 bp) 5'-GGAAATATGGCGCACGCT-3' (sense); 5'-TCACTTGTGGCCCAGAT3' (anti-sense); bax (508 bp) 5'-CCAGCTCTGAGCAGATCAT-3' (sense), 5'-TATCAGCCCATCTTCTTCC-3' (antisense). Polymerse chain reactions were performed in a $50 \mu \mathrm{l}$ reaction volume. PCR products were electrophoresed on agarose gel, and photographed under UV light, after staining with ethidium bromide.

Data Analyses Data were analyzed by one-way ANOVA, Student's $t$-test or Tukey's HSD test.

\section{RESULTS}

Tumor Inhibition Rate and Morphological Changes by SAMC An inhibitory effect was observed in all therapeutic groups and the inhibition rate by SAMC at the dose of $100 \mathrm{mg} / \mathrm{kg}$ and $300 \mathrm{mg} / \mathrm{kg}$ was $31.36 \%$ and $37.78 \%$. This showed significance at $p<0.05$ and $p<0.01$ vs. control group, respectively. The inhibition rate by the positive control, Adriamycin, at $2 \mathrm{mg} / \mathrm{kg}$ was $49.18 \%(p<0.01)$ (Table $1)$. The cells in the control group had normal morphological structures, but some cells in the therapeutic groups (SAMC, $100,300 \mathrm{mg} / \mathrm{kg}$ ) had apoptotic characteristics including chro- 
Table 1. Inhibitory Effect of SAMC on Tumor Volume of Implanted Tumors in Nude Mice (Mean \pm S.D.)

\begin{tabular}{|c|c|c|c|c|c|}
\hline \multirow{2}{*}{ Group } & \multicolumn{2}{|c|}{ Number of animals } & \multicolumn{2}{|c|}{ Volume of tumors $\left(\mathrm{mm}^{3}\right)$} & \multirow{2}{*}{$\begin{array}{c}\text { Inhibition } \\
\text { rate } \\
\%\end{array}$} \\
\hline & Beginning & Ending & Beginning & Ending & \\
\hline \multicolumn{6}{|l|}{ Control group } \\
\hline $10 \%(\mathrm{w} / \mathrm{v})$ dextrose $+1 \%(\mathrm{w} / \mathrm{v})$ gum arabic & 7 & 7 & $40.36 \pm 12.33$ & $2075.04 \pm 330.72$ & \\
\hline \multicolumn{6}{|l|}{ SAMC } \\
\hline $100 \mathrm{mg} / \mathrm{kg}$ & 7 & 7 & $42.01 \pm 14.12$ & $1438.28 \pm 406.09^{*}$ & 31.36 \\
\hline $300 \mathrm{mg} / \mathrm{kg}$ & 7 & 7 & $46.26 \pm 13.20$ & $1311.97 \pm 109.97 * *$ & 37.78 \\
\hline Positive control adriamycin ( $2 \mathrm{mg} / \mathrm{kg})$ & 7 & 7 & $51.36 \pm 11.36$ & $1085.23 \pm 396.49 * *$ & 49.18 \\
\hline
\end{tabular}

$* p<0.05, * * p<0.01 v s$. control group by student's $t$-test.
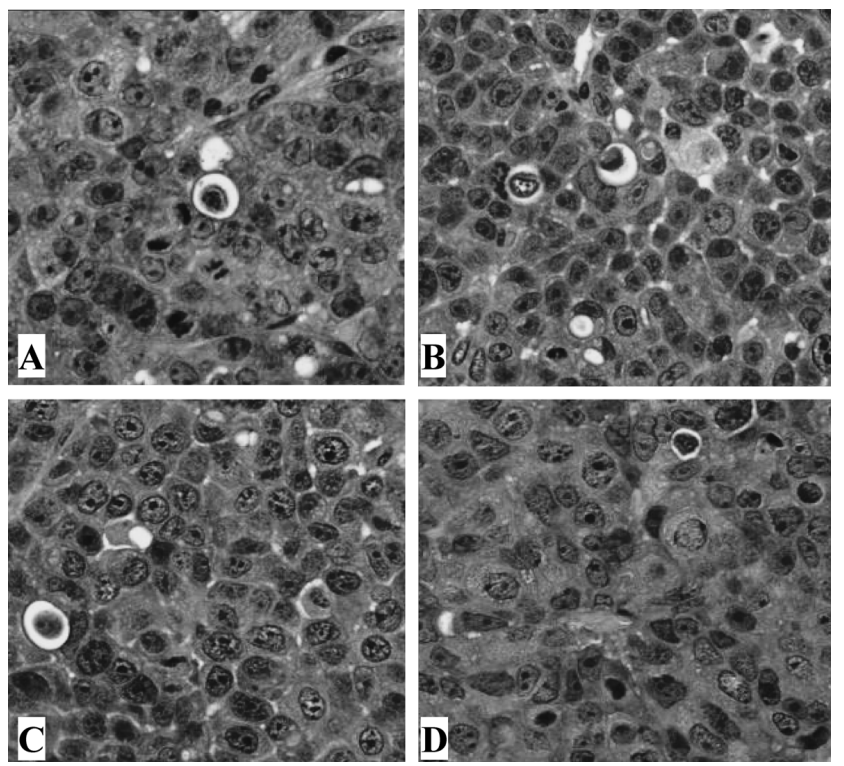

Fig. 1. Microscopic Structures of Transplanted Tumor Cells and Apoptotic Transplanted Tumor Cells Induced by SAMC (Original Magnification: $\times 1000)$ of H\&E Staining

Animal ID: 5 (A: control), 10 (B: SAMC, $100 \mathrm{mg} / \mathrm{kg}$ ), 20 (C: SAMC, $300 \mathrm{mg} / \mathrm{kg}$ ) and 26 (D: adriamycin, $2 \mathrm{mg} / \mathrm{kg}$ ).

matin crescent, cell shrinkage and membrane blebbing (Fig. 1). Positive control (Adriamycin, $2 \mathrm{mg} / \mathrm{kg}$ ) induced more drastic apoptotic characteristics.

Apoptotic Tumor Cells by SAMC Positive staining was clear in nuclei (Fig. 2). The apoptosis index of control, $100 \mathrm{mg} / \mathrm{kg}$ SAMC and $300 \mathrm{mg} / \mathrm{kg}$ SAMC was $4.42 \pm 0.63$, $20.74 \pm 2.50$ and $30.61 \pm 2.42$, respectively. These showed significance at $p<0.01 v s$. control group. The AI value of the positive control, Adriamycin $(2 \mathrm{mg} / \mathrm{kg})$ was $42.01 \pm 3.01$ $(p<0.01)$ (Table 2).

Expression of Bcl-2 and Bax Proteins Positive staining was located in the cytoplasm. The positive rate of bcl-2 protein expression in control, $100 \mathrm{mg} / \mathrm{kg}$ SAMC and $300 \mathrm{mg} / \mathrm{kg}$ SAMC was $15.20 \pm 1.67 \%, 10.94 \pm 1.57 \%$ and $8.24 \pm 1.07 \%$ $(p<0.05)$, respectively. The positive rate of the positive control, Adriamycin $(2 \mathrm{mg} / \mathrm{kg})$, was $5.30 \pm 1.18 \%(p<0.01)$. The positive rate of bax protein expression in control, $100 \mathrm{mg} / \mathrm{kg}$ $\mathrm{SAMC}$ and $300 \mathrm{mg} / \mathrm{kg}$ SAMC was $15.30 \pm 1.90 \%, 23.18 \pm$ $1.81 \%$, and $25.26 \pm 3.03 \%(p<0.05)$, respectively, by immunohistochemical staining. The positive rate of the positive control, $2 \mathrm{mg} / \mathrm{kg}$ Adriamycin, was $26.60 \pm 1.82 \%(p<0.05)$. $300 \mathrm{mg} / \mathrm{kg}$ SAMC and $2 \mathrm{mg} / \mathrm{kg}$ Adriamycin showed signifi-
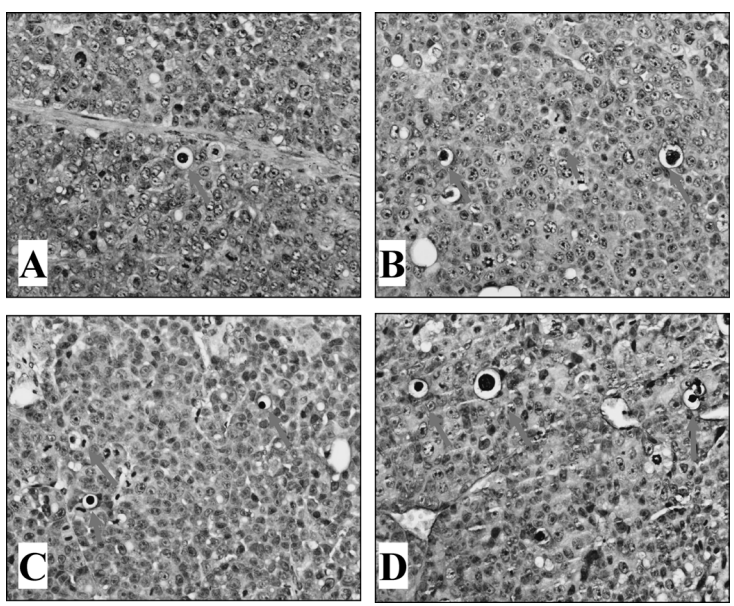

Fig. 2. Apoptotic Tumor Cells/Human Stomach Cancer MKN-45 Cell Line Xenograft (Original Magnification: $\times 400)$

TUNEL positive cells are observed in the tumor mass (arrows). Animal ID: 5 (A: control), 10 (B: SAMC, $100 \mathrm{mg} / \mathrm{kg}$ ), 20 (C: SAMC, $300 \mathrm{mg} / \mathrm{kg}$ ) and 26 (D: adriamycin, $2 \mathrm{mg} / \mathrm{kg}$ ).

Table 2. Apoptotic Index (AI) of Implanted Tumors in Nude Mice (Mean \pm S.D.)

\begin{tabular}{ccccc}
\hline \hline Control & $\begin{array}{c}\text { SAMC } \\
100 \mathrm{mg} / \mathrm{kg}\end{array}$ & $\begin{array}{c}\text { SAMC } \\
300 \mathrm{mg} / \mathrm{kg}\end{array}$ & $\begin{array}{c}\text { Adriamycin } \\
2 \mathrm{mg} / \mathrm{kg}\end{array}$ \\
\hline AI (\%) & $4.42 \pm 0.63$ & $20.74 \pm 2.50^{* *}$ & $30.61 \pm 2.42^{* * *}$ & $42.01 \pm 3.01 * *$ \\
\hline
\end{tabular}

$* * p<0.01 v s$. control group by student's $t$-test.

Table 3. Positive Rate of Bcl-2 and Bax Proteins of Implanted Tumors in Nude Mice

\begin{tabular}{lcc}
\hline \hline & $\begin{array}{c}\text { Bcl-2 (\%) } \\
\text { Mean } \pm \text { S.E. }\end{array}$ & $\begin{array}{c}\text { Bax (\%) } \\
\text { Mean } \pm \text { S.E. }\end{array}$ \\
\hline Control & $15.20 \pm 1.67$ & $15.30 \pm 1.90$ \\
SAMC $100 \mathrm{mg} / \mathrm{kg}$ & $10.94 \pm 1.57$ & $23.18 \pm 1.81$ \\
SAMC $300 \mathrm{mg} / \mathrm{kg}$ & $8.24 \pm 1.07^{*}$ & $25.26 \pm 3.03^{*}$ \\
Adriamycin $2 \mathrm{mg} / \mathrm{kg}$ & $5.30 \pm 1.18^{* *}$ & $26.60 \pm 1.82^{*}$
\end{tabular}

$* p<0.05, * * p<0.01 v s$. control group by Turkey HSD test.

cance at the 5\% level (Table 3).

Expression of Bcl-2 and Bax mRNA The density of bax mRNA in control, $100 \mathrm{mg} / \mathrm{kg}$ SAMC, $300 \mathrm{mg} / \mathrm{kg}$ SAMC and Adriamycin was increased progressively, and the density of bcl-2 mRNA in control, $100 \mathrm{mg} / \mathrm{kg}$ SAMC, $300 \mathrm{mg} / \mathrm{kg}$ SAMC and Adriamycin decreased progressively according to RT-PCR (Fig. 3). 


\section{$\mathrm{SAMC}(\mathrm{mg} / \mathrm{Kg})$}

$0 \quad 100 \quad 300 \quad$ adriamycin

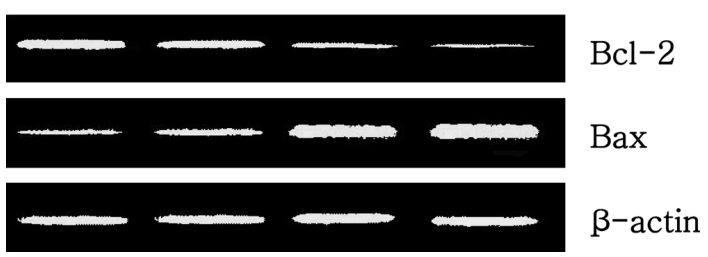

Fig. 3. Expression of Bcl-2 mRNA and Bax mRNA in Apoptotic Transplanted Tumor Cells Induced by SAMC

Total RNA was extracted, and of bcl-2, bax and $\beta$-actin mRNA levels were determined by RT-PCR. $\beta$-Actin was used as an internal control.

\section{DISCUSSION}

Uncovering new anti-tumor drugs with less toxicity is an ongoing challenge in cancer research. The original source of SAMC, garlic, a plant within the Allium genus, has been used in many different cultures for disease prevention and treatment, especially for diseases of the gastrointestinal tract. Epidemiological investigations in China, Italy, and America have provided evidence that regular consumption of garlic and related garlic products decreases the risks of stomach and colon cancers. ${ }^{30)}$ Although not present in raw garlic, SAMC is a major in vivo metabolic product of the garlic compounds allicine and diallyl disulfides, ${ }^{36)}$ both of which are well known to show anticancer properties. ${ }^{37-40)}$ This allylmercapto glutathione $S$-conjugate, SAMC, which is biotransformed from allyl sulfides and from the naturally occurring water-soluble garlic derivatives, also inhibits tumorigenesis. ${ }^{30)}$ SAMC also reportedly inhibits growth and induces apoptosis in SW480 and HT 29 human colon cancer cells, ${ }^{32)}$ and prostate cancer cells. ${ }^{33)}$ This anticancer activity of SAMC in vitro ${ }^{30-34)}$ might be related to the induction of tumor cell apoptosis.

In a previous study, we showed that SAMC was able to induce apoptosis in gastric cancer cells. The apoptosis accompanied down-regulation of the anti-apoptotic gene, bcl-2, at the same time as up-regulation of the pro-apoptotic gene, bax. In this study, we evaluated the apoptotic effect of SAMC on an implanted tumor of gastric cancer cells, and investigated the molecular mechanisms further to provide a theoretical basis for the therapeutic application of SAMC. We observed the inhibitory effect of SAMC in two therapeutic groups. Tumor cells in the control group had normal structures, but some tumor cells in the therapeutic groups had apoptotic characteristics. The apoptosis index of SAMC at doses of 100 and $300 \mathrm{mg} / \mathrm{kg}$ was increased. The protein level of bcl-2 was decreased with SAMC at doses of 100 and $300 \mathrm{mg} / \mathrm{kg}$, but that of bax was increased. The density of bcl2 mRNA induced by SAMC at doses of 100 and $300 \mathrm{mg} / \mathrm{kg}$ decreased progressively and the density of bax mRNA increased progressively. We hypothesized that the lowered ratio of $\mathrm{bcl}-2 / \mathrm{bax}$ by the altered transcriptional regulation by SAMC triggered the apoptosis of implanted tumor cells. Our results demonstrate that SAMC was able to induce the apoptosis of implanted tumors of gastric cancer cells in nude mice. SAMC may be involved in down-regulating the expression of the apoptosis-regulated gene bcl-2 and up-regulating the expression of the pro-apoptotic gene bax. These data suggest that SAMC may be used as a chemotherapeutic drug in anti-tumor chemotherapy.

Acknowledgements This work was supported by Dongseo University, "Dongseo Frontier Project" Research Fund of 2009.

\section{REFERENCES}

1) Adams J. M., Cory S., Trends Biochem. Sci., 26, 61-66 (2001).

2) van der Woude C. J., Jansen P. L., Tiebosch A. T., Beuving A., Homan M., Kleibeuker J. H., Moshage H., Hum. Pathol., 33, 686-692 (2002).

3) Panaretakis T., Pokrovskaja K., Shoshan M. C., Grander D., J. Biol. Chem., 277, 44317-44326 (2002).

4) Bellosillo B., Villamor N., Lopez-Guillermo A., Marce S., Bosch F., Campo E., Montserrat E., Colomer D., Blood, 100, 1810-1816 (2002).

5) Zamzami N., Brenner C., Marzo I., Susin S. A., Kroemer G., Oncogene, 16, 2265-2282 (1998).

6) Chao D. T., Korsmeyer S. J., Annu. Rev. Immunol., 16, 395-419 (1998).

7) Hsu Y. T., Wolter K. G., Youle R. J., Proc. Natl. Acad. Sci. U.S.A., 94, 3668-3672 (1997).

8) Rosse T., Olivier R., Monney L., Rager M., Conus S., Fellay I., Jansen B., Borner C., Nature (London), 391, 496-499 (1998).

9) Finucanne D. M., Bossy-Wetzel E., Waterhouse N. J., Cotter T. G., Green D. R., J. Biol. Chem., 274, 2225-2233 (1999).

10) Ito T., Deng X., Carr B., May W. S., J. Biol. Chem., 272, 1167111673 (1997).

11) Chang W. K., Yang K. D., Chuang H., Jan J. T., Shaio M. F., Clin. Immunol., 104, 151-160 (2002).

12) Lanzi C., Cassinelli G., Cuccuru G., Supino R., Zuco V., Ferlini C., Scambia G., Junino F., Prostate, 48, 254-264 (2001).

13) Miyashita T., Krajewski S., Krajewska M., Wang H. G., Lin H. K., Liebermann D. A., Hoffman B., Reed J. C., Oncogene, 9, 1799-1805 (1994).

14) Mertens H. J., Heineman M. J., Evers J. L., Gynecol. Obstet. Invest., 53, 224-230 (2002).

15) Mehta U., Kang B. P., Bansal G., Bansal M. P., Gen. Physiol. Biophys., 21, 15-29 (2002).

16) Gabriel N., Michael F. C., Trends Cell Biol., 4, 399-403 (1994).

17) Chen G. G., Lai P. B., Hu X., Lam I. K., Chak E. C., Chun Y. S., Lau W. Y., Clin. Exp. Metastasis, 19, 457-464 (2002).

18) Usuda J., Chiu S. M., Azizuddin K., Xue L. Y., Lam M., Nieminen A. L., Oleinick N. L., Photochem. Photobiol., 76, 217-223 (2002).

19) Sun F., Akazawa S., Eguchi K., Koji T., Arch. Histol. Cytol., 65, 145 157 (2002).

20) Jang M. H., Shin M. C., Shin H. S., Kim K. H., Park H. J., Kim E. H., Kim C. J., Eur. J. Pharmacol., 449, 39-45 (2002).

21) Pettersson F., Dalgleish A. G., Bissonnette R. P., Colston K. W., Br. J. Cancer, 87, 555-561 (2002).

22) Fujita K., Kimura M., Kondo N., Sakakbara A., Sano D., Ishigura Y., Tsukuda M., Oncology Reports, 20, 1363-1368 (2008).

23) Howard E. W., Ling M. T., Chua C. W., Cheung H. W., Wang X., Wong Y. C., Clin. Cancer Res., 13, 1847-1856 (2007).

24) Schluep T., Gunawan P., Ma L., Jensen G. S., Duringer J., Hinton S., Rchter S., Hwang J., Clin. Cancer Res., 15, 181-189 (2009).

25) Wargovich M. J., Carcinogenesis, 8, 487-489 (1987).

26) Sundaram S. G., Milner J. A., Cancer Lett., 74, 85-90 (1993).

27) Sakamoto K., Lawson L. D., Milner J. A., Nutr. Cancer, 29, 152-156 (1996).

28) Weisberger A., Pensky J., Cancer Res., 18, 1301-1308 (1958).

29) Stipanuk M. H., Mondono M., Lee J. I., Hu M., Yu A. F., J. Nutr., 132, 3369-3378 (2002)

30) Pinto J. T., Lapsia S., Shah A., Santiago H., Kim G., "Nutrition and Cancer Prevention: New Insights into the Role of Phytochemicals," ed. by American Institute for Cancer Research, Kluwer Academic/Plenum Publishers, New York, 1975.

31) Xiao D., Pinto J. T., Soh J. W., Cancer Res., 63, 6825-6837 (2003).

32) Shirin H., Pinto J. T., Kawabata Y., Soh J. W., Delohory T., Moss S. F., 
Murty V., Rivlin R. S., Holt P. R., Weinstein I. B., Cancer Res., 61, 725-731 (2001).

33) Pinto J. T., Qiao C., Xing J., Prostate, 45, 304-314 (2000).

34) Lee Y. K., Int. J. Mol. Med., 20, 765-770 (2008).

35) "Guide for the Care and Use of Laboratory Animals," ed. by Institute of Laboratory Animal Resources Commission on Life Sciences, National Research Council, National Academy Press, Washington, DC, 1996.

36) Lawson L. D., Wang Z. J., Planta Med., 59 (Suppl.), A688-A689
(1993).

37) EL-Bayoumy K., Sinha R., Pinto J. T., Rivlin R. S., J. Nutr., 136, 864S-869S (2006).

38) Sundaram S., Milner J., J. Nutr., 126, 1355-1361 (1996).

39) Amagenase H., Petesch B. L., Matsuura H., Kasuga S., Itakura Y., J. Nutr., 131, 955S-962S (2001).

40) Hsing A. W., Chokkalingam A. P., Gao Y. T., J. Natl. Cancer Inst., 94, $1648-1651$ (2002). 